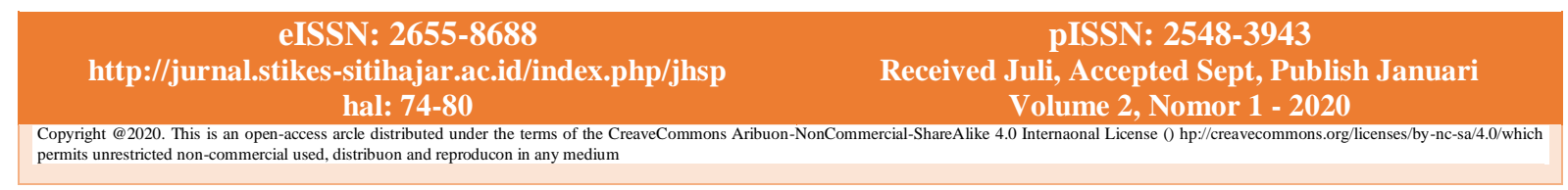

\title{
Pendekatan Diagnosis Terbaru Vaping Associated Pulmonary Injury (VAPI)
}

\author{
Anisa Ramadhanti ${ }^{*}$ \\ ${ }^{1}$ Program Studi Pendidikan Dokter, Fakultas Kedokteran, Universitas Lampung \\ Email: aramadhanti50@gmail.com
}

\begin{abstract}
ABSTRAK
Rokok elektronik atau vape diklaim lebih aman dan lebih tidak berbahaya karena lebih sedikit mengandung bahan kimia toksik dibandingkan rokok konvensional. Walaupun demikian, masih banyak pihak yang mempertanyakan keamanan rokok elektronik. Liquid dalam rokok elektronik dan aerosol yang dihasilkan terbukti mengandung sejumlah komponen kimia yang kemungkinan memiliki efek yang berbahaya terhadap kesehatan, terutama paru yang dapat menyebabkan vaping-associated pulmonary injury (VAPI). Berdasarkan laporan kasus sebelumnya, VAPI terbagi menjadi beberapa spektrum penyakit, diantaranya adalah pneumonia eosinofilik akut, organizing pneumonia, lipoid pneumonia, kerusakan alveolus difus, dan acute respiratory distress syndrome (ARDS), perdarahan alveolar difus, pneumonitis hipersensitif, dan yang paling jarang yaitu giant-cell interstitial pneumonitis. Terdapat definisi kasus yang terbaru dalam menegakkan diagnosis VAPI, serta tatalaksana.
\end{abstract}

Kata Kunci : ARDS, Pneumonia, Rokok elektronik, VAPI

\section{Recent Advances in the Diagnosis of Vaping Associated Pulmonary Injury (VAPI)}

\begin{abstract}
Electronic cigarettes or vapes are claimed more safety and less harmful, because contain fewer toxic chemicals than conventional cigarettes. Although, there are still many people who still doubt the safety of electronic cigarettes. Liquid in electronic cigarettes and aerosol are contain a number of chemical components that may have harmful effects on health, especially the lungs, which can cause vaping-associated pulmonary injury (VAPI). Based on previous case reports, VAPI has divided into spectrum of diseases that include acute eosinophilic pneumonia, organizing pneumonia, lipoid pneumonia, diffuse alveolar damage and acute respiratory distress syndrome (ARDS), diffuse alveolar hemorrhage, hypersensitivity pneumonitis, and the rare giant-cell interstitial pneu- monitis. There is recent case definition to establish the diagnosis of VAPI, and management.
\end{abstract}

Keywords : ARDS, Electronic cigarettes, Pneumonia, VAPI 


\section{Pendahuluan}

Secara global, konsumsi tembakau melalui rokok konvensional mengalami peningkatan terutama di negara berkembang (Tobacco Control Support Centre, 2015). Secara nasional, jumlah perokok tembakau cukup tinggi yaitu sebesar 29\% (Kemenkes RI, 2018). Tembakau menjadi penyebab tunggal kematian utama karena menyebabkan penyakit yang dapat mengancam nyawa, diantaranya kanker paru, stroke, penyakit paru obstruktif kronik (PPOK), penyakit jantung koroner (PJK), dan gangguan pembuluh darah (Tobacco Control Support Centre, 2015). Sementara itu beberapa tahun terakhir, rokok elektronik diperkenalkan sebagai alternatif dari rokok konvensional dengan tujuan untuk menghindari dampak bahaya rokok konvensional yang menggunakan tembakau (Cho et al., 2011). Berdasarkan studi terkait rokok elektronik di Indonesia, didapatkan sebanyak 2,1\% responden yang menggunakan rokok elektronik, dan sekitar 47\% dari sampel berusia 25-45 tahun (Elsa dan Nadjib, 2019).

Rokok elektronik merupakan alat yang menggunakan baterai untuk memanaskan cairan atau liquid menjadi bentuk aerosol yang dapat dihirup oleh pengguna. Rokok elektronik diklaim lebih aman karena mengandung lebih sedikit bahan kimia toksik dibandingkan rokok konvensional. Rokok elektronik menggunakan liquid yang umumnya mengandung propylene glycol dan gliserol sebagai pelarut, ditambah dengan nikotin untuk dihirup dan terkadang juga digunakan untuk menghirup substansi seperti tetrahydrocannabinol (THC) dan cannabidiol (CBD). Selain itu, beberapa substansi lainnya yang terdeteksi yaitu hidrokarbon aromatik, nitrosamine, volatil organik, dan bahan kimia anorganik seperti metal toksik (Layden et al., 2019).

Rokok elektronik diklaim lebih aman karena lebih sedikit menghasilkan asap. Walaupun demikian, masih banyak pihak yang mempertanyakan keamanan rokok elektronik. Secara umum, orang yang telah berhenti merokok tembakau cenderung beralih ke rokok elektronik sebagai alternatif dari rokok tembakau, akan tetapi perokok elektronik masih hawatir dengan potensi racun yang berhaya dari rokok tersebut (Goniewics et al., 2013). Selain itu, mayoritas rokok elektronik tidak memberikan informasi detail kandungan dalam liquid yang digunakan pada rokok elektronik (Cheng, 2014). Padahal cukup banyak laporan kasus yang melaporkan penyakit akibat penggunaan rokok elektronik, terutama terkait sistem respirasi, atau bahkan kardiovaskular. Suatu penelitian menyatakan bahwa pengguna rokok elektronik lebih berisiko terkena stroke dengan odds ratio sebesar 1,71, dibandingkan dengan bukan pengguna rokok elektronik (Ndunda dan Muutu, 2019). Sama seperti gangguan pernapasan akibat rokok elektronik, stroke juga dapat menjadi fatal apabila tidak ditangani dan perlu dicegah sejak dini dengan memberikan penyuluhan kesehatan dan penanganan fisioterapi berupa pemberian sinar infra red (Sulaiman dan Anggraini, 2017)

dan aerosol yang dihasilkan terbukti mengandung sejumlah komponen kimia yang kemungkinan memiliki efek yang berbahaya terhadap kesehatan (Floyd et al.,2018). Selain itu, liquid rokok elektronik yang mengandung nikotin telah dikaitkan dengan manifestasi penyakit yang bervariasi. Penyakit paru interstitial akut seperti pneumonia eosinofilik akut, bronchiolitis-associated interstitial lung disease, dan pneumonitis hipersensitif, telah dikaitkan dengan penggunaan liquid rokok elektronik yang mengandung nikotin (Layden et al., 2019). Pada suatu penelitian mengenai penyakit paru akibat penggunaan rokok elektronik, dilaporkan bahwa mayoritas gejala respirasi yang dialami oleh pasien yaitu nafas yang pendek (87\%), diikuti dengan batuk (83\%), dan nyeri dada (55\%) (Henry et al., 2020).

Terdapat banyak laporan kasus yang melaporkan penyakit paru yang berkaitan dengan penggunaan rokok elektronik yang dinamakan vaping associated pulmonary injury (VAPI). Berdasarkan laporan kasus sebelumnya, VAPI terbagi menjadi beberapa spektrum penyakit, diantaranya adalah pneumonia eosinofilik akut, organizing pneumonia, lipoid pneumonia, kerusakan alveolus difus, dan acute respiratory distress syndrome (ARDS), perdarahan alveolar difus, pneumonitis hipersensitif, dan yang paling jarang yaitu giant-cell interstitial 
pneumonitis (Christiani, 2019). Seiring mulai bertambahnya tren penggunaan rokok elektronik di masyarakat, diperlukan upaya pencegahan melalui pengetahuan tentang bahaya, dan upaya manajemen melalui penegakan diagnosis dan tatalaksana yang tepat. Maka itu, tinjauan pustaka berikut ini bertujuan untuk mengkaji tentang pendekatan diagnosis dan tatalaksana berdasarkan literatur dan laporan kasus yang telah ada sebelumnya.

\section{Pembahasan}

\section{Vaping Associated Pulmonary Injury (VAPI)}

Penyakit VAPI telah ditetapkan sebagai penyakit paru akibat penggunaan rokok elektronik atau vape. Penyakit VAPI terbagi menjadi beberapa spektrum penyakit, diantaranya adalah pneumonia eosinofilik akut, organizing pneumonia, lipoid pneumonia, kerusakan alveolus difus, dan acute respiratory distress syndrome (ARDS), perdarahan alveolar difus, pneumonitis hipersensitif, dan yang paling jarang yaitu giant-cell interstitial pneumonitis (Christiani, 2019). Pneumonia eosinofilik akut merupakan penyakit yang ditandai dengan hipoksemia, infiltrat paru, dan peningkatan eosinofil. Penumonia eosinofilik akut dapat terjadi karena paparan obat, atau reaksi hipersensitivitas akibat antigen yang terhirup (Kamada et al., 2016)

\section{Patofisiologi VAPI}

Rokok elektronik dapat menyebabkan kerusakan pada paru-paru melalui berbagai mekanisme, salah satunya dengan mengubah ekspresi protein dalam sel epitel bronkial, sekresi protein dan apoptosis. Paparan akut terhadap uap rokok elektronik telah terbukti mengurangi gerakan silia dengan cepat, menghambat fungsi mitokondria, dan mengubah ekspresi gen yang terlibat dalam jalur stres oksidatif. Peningkatan kadar mucin MUC5AC telah ditemukan baik di epitel bronkial dan dalam sekresi saluran pernapasan.55 Peningkatan kadar mисin berkorelasi terbalik dengan penurunan fungsi paru-paru pada pasien PPOK dan merupakan biomarker bronkitis kronis 5859 (Gotts et al., 2019).

Sementara itu, substrat dalam rokok elektronik dapat mempengaruhi jalur biokimia yang berbeda. Salah satunya adalah propilen glikol dan gliserin nabati yang merupakan perantara nikotin, telah terbukti menginduksi remodeling saluran pernapasan. Uap rokok elektronik, baik yang mengandung nikotin maupun bebas nikotin, dapat berbahaya karena mengaktivasi makrofag alveolar akibat adanya radikal bebas, partikulat, formaldehida, nitrosamin, senyawa organik yang mudah menguap, dan hidrokarbon aromatik (Triantafyllou et al., 2019) Substrat dalam rokok elektronik dapat memicu apoptosis makrofag alveolus, meningkatkan sekresi sitokin pro-inflamasi, dan mengganggu fagositosis (Gotts et al., 2019). Zat penambah rasa juga dapat berbahaya, seperti cinnamaldehyde yang dapat menghambat fungsi mitokondria, mengganggu proses bioenergi, dan mengurangi kadar adenosin trifosfat dalam epitel pernapasan (Triantafyllou et al., 2019).

Sementara itu, pneumonia lipoid akut juga dapat dialami oleh pengguna rokok elektronik. Penjelasan mengenai hal tersebut adalah bahwa minyak aerosol yang dihirup akan disimpan dalam saluran pernapasan distal serta alveolus, kemudian akan memicu respon inflamasi lokal yang mengganggu proses pertukaran gas. Pneumonia lipoid disebabkan dari aspirasi minyak ke dalam paru-paru dan telah dikaitkan dengan penggunaan rokok elektronik dalam beberapa laporan kasus (Davidson et al., 2019). Selain itu, gliserin dalam rokok elektronik juga dikaitkan dengan timbulnya pneumonia lipoid (McCauley et al., 2012). 


\section{Diagnosis VAPI}

Diagnosis VAPI untuk masing-masing spektrum klinis dapat ditegakkan melalui anamnesis, pemeriksaan fisik, pemeriksaan penunjang berupa rontgen regio toraks, histopatologis dan CT-scan. Manifestasi klinis VAPI tidak spesifik, mayoritas pasien mengalami gejala dyspnea dan batuk. Pemeriksaan laboratorium mayoritas menunjukkan peningkatan kadar protein C-reaktif. Cairan bronchoalveolar lavage (BAL) menunjukkan dominasi neutrofilik (49\%) dan lebih dari 50\% lipid layden macrophages khususnya pada pneumonia lipoid (Maddock et al., 2019). Pada umumnya, hasil pemeriksaan CT-Scan regio thorax pada VAPI menunjukkan ground-glass opacities yang terjadi bilateral (Itoh et al., 2018)

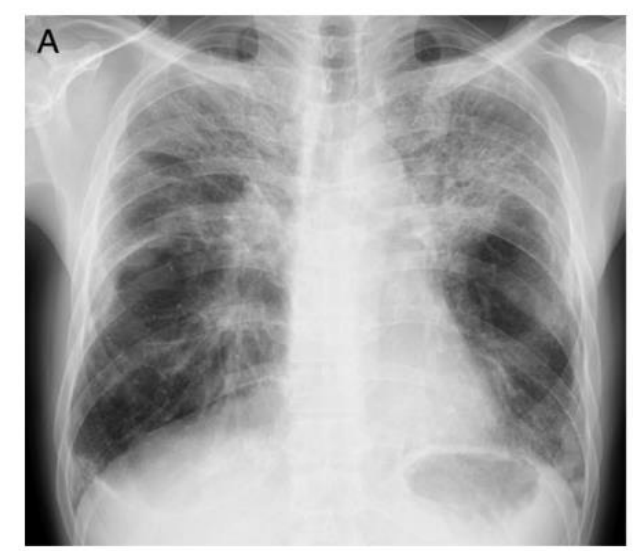

Gambar 1: Gambaran Radiologis ground-glass opacities pada VAPI (Itoh et al., 2018)

Pada pneumonia eosinofilik akut dominan terdapat efusi pleura, penebalan septum dan ground-glass opacities bilateral paru (Aokage et al., 2019). Pneumonia eosinofilik akut ditandai dengan gagal napas disertai demam akut, dan terdapat dominan sel eosinofil serta infiltrat radiografi difus. Kriteria diagnostik pneumonia eosinofilik akut meliputi: timbulnya gejala akut tujuh hari atau kurang, demam $\geq 37.2^{\circ} \mathrm{C}$, infiltrat bilateral pada rontgen regio toraks; hipoksemia berat, eosinofilia pada BAL dengan eosinofil $\geq 25 \%$ atau dominasi eosinofil pada biopsi paru terbuka. Hipoksemia berat ditandai dengan tekanan parsial oksigen arteri (PaO2) $\leq 60, \mathrm{SpO} 2<90 \%$. Selain itu, diagnosis pneumonia eosinofilik akut dapat ditegakkan bila tidak ada riwayat hipersensitivitas obat, tidak ada bukti riwayat atau hasil pemeriksaan laboratorium terkait infeksi lain, dan tidak ada penyebab lain yang teridentifikasi selain pneumonia eosinofilik akut (Allen, 2006)

Sementara itu, gambaran CT-Scan pada pola organizing pneumonia menunjukkan celah di sepanjang tepi paru atau peripheral sparing dan nodul ground-glass multipel (Khan et al., 2018). Pada suatu laporan kasus terkait pasien yang menggunakan rokok elektronik, melaporkan bahwa pasien tersebut mengalami gejala sulit bernapas, batuk dan hemoptisis serta menunjukkan karakteristik dari organizing pneumonia. Pada pemeriksaan CT scan menunjukkan terdapat beberapa nodul kecil pada kedua sisi paru-paru (Mantilla et al., 2016). Sementara itu, laporan kasus lainnya yang serupa menunjukkan pemeriksaan CT scan yang sedikit berbeda, yaitu gambaran kekeruhan bilateral diskret, konsolidasi ground-glass konfluen, dan konsolidasi yang jga merupakan karakteristik dari organizing-pneumonia (Khan et al., 2018).

Diagnosis pneumonia lipoid didasarkan pada riwayat penggunaan rokok elektronik yang pada liquid mengandung lipid, hasil pemeriksaan radiologis, gambaran lipid-laden macrophages dari sekret atau sampel respirasi, dan telah dieksklusikan dari kemungkinan diagnosis alternatif lainnya. Lipid-laden macrophages paling baik ditemukan dengan menggunakan pewarnaan lipid khusus seperti minyak red-O atau pewarnaan sudan dari cairan atau sekret bronkoalveolar (Davidson et al., 2019). 
Pneumonia lipoid eksogen dapat muncul dengan hipoksia atau alkalosis pernapasan, tergantung dengan tingkat keparahan penyakit. Hasil tes fungsi paru umumnya menunjukkan gangguan ventilasi tipe restriktif dan/atau gangguan difusi. Hasil pemeriksaan radiografi regio toraks sering menunjukkan gambaran konsolidasi alveolar bilateral yang luas dan opasitas ground-glass pada area tertentu. Namun, dapat hanya melibatkan satu sisi paru atau unilateral pada paru-paru kanan atau kiri secara merata (McCauley et al., 2012). Selain itu, pada pemeriksaan CT resolusi tinggi sering ditemukan konsolidasi alveolar posterior dan lobus bawah yang dominan, opasitas ground-glass, dan pola "crazy paving". Area yang terkonsolidasi umumnya akan terlihat hipodense, dengan atenuasi yang mirip dengan jaringan adiposa di sekitarnya (McCauley et al., 2012).

Definisi kasus untuk diagnosis VAPI telah dikategorikan menjadi confirmed case dan probable case. Kriteria confirmed case yaitu penggunaan rokok elektronik (vaping) dalam 90 hari sebelum timbul gejala, dan terdapat Infiltrat paru berupa kekeruhan pada rontgen toraks, atau opasitas ground-glass CT-scan. Selain itu, tidak adanya bukti infeksi paru pada pemeriksaan awal. Seluruh pemeriksaan klinis lainnya terkait penyakit infeksi pernapasan dengan hasil negatif misalnya pada tes antigen Streptococcus pneumoniae dan legionella, biakan dahak apabila terdapat batuk produktif, biakan bronchoalveolar-lavage (BAL) jika dilakukan, kultur darah, dan tidak ada bukti infeksi oportunistik HIV. Selain itu, tidak ada bukti dan riwayat diagnosis alternatif yang masuk akal (misalnya penyakit jantung, reumatologis, atau proses neoplastik) Sementara itu, kriteria probable case juga meliputi penggunaan rokok elektronik (vaping) dalam 90 hari sebelum timbul gejala, dan terdapat Infiltrat paru berupa kekeruhan pada rontgen toraks, atau opasitas ground-glass CT-scan. Namun, terdapat infeksi yang diidentifikasi melalui kultur atau polymerase chain reaction (PCR), tetapi tim klinis yang merawat pasien meyakini bahwa hal tersebut bukan satu-satunya penyebab penyakit pernapasan yang mendasarinya atau pengujian tidak dilakukan untuk mengesampingkan infeksi paru lain. Selain itu, tidak ada pula bukti atau riwayat diagnosis alternatif yang masuk akal (mis. proses jantung, reumatologis, atau neoplastik) (Layden et al., 2019)

\section{Tatalaksana VAPI}

Tatalaksana VAPI belum terdapat standar pengobatan secara resmi, namun mayoritas laporan kasus menggunakan steroid. Pada sauatu kasus, tatalaksana yang diberikan pada awalnya adalah antibiotik amoksisilin dan azitromisin sebagai terapi empiris untuk pneumonia atipikal dan berbasis komunitas, serta oksigen 3 liter per menit melalui nasal kanul. Selain itu, pasien juga diintubasi dan dipasang ventilasi mekanik. Namun setelah 12 jam, dilakukan pemeriksaan rontgen toraks menunjukan perburukan. Setelah melakukan pemeriksaan untuk memastikan tidak ada infeksi dan penyakit lainnya, pasien mulai diberikan glukokortikoid ntravena dosis tinggi selama 2 hari, dan antibiotik dihentikan. Setelah 3 hari keadaan pasien membaik dan dilakukan ekstubasi (Layden et al., 2019).

Pada kasus lainnya, setelah dipastikan tidak ada bukti infeksi lainnya, pasien diberikan metilprednisolon $1 \mathrm{mg} / \mathrm{KgBB}$ dan 7 hari kemudian kondisi pasien membaik. Sebelumnya juga dilakukan intubasi pada pasien (Maddock et al., 2019). Tatalaksana serupa juga diberikan pada kasus lainnya, yaitu metilprednisolon $120 \mathrm{mg}-500 \mathrm{mg}$ per hari secara intravena, kemudian pasien membaik secara klinis dalam 24-72 jam kemudian. Kemudian pasien diperbolehkan rawat jalan dan diberikan prednison per oral (Davidson et al., 2019) 


\section{Kesimpulan}

Rokok elektronik telah dinyatakan dapat berbahaya bagi kesehatan terutama menyebabkan vaping-associated pulmonary injury (VAPI) dengan sperktrum klinis pneumonia eosinofilik akut, organizing pneumonia, lipoid pneumonia, kerusakan alveolus difus, dan acute respiratory distress syndrome (ARDS), perdarahan alveolar difus, pneumonitis hipersensitif, dan yang paling jarang yaitu giant-cell interstitial pneumonitis. Kriteria diagnosis dapat ditegakkan secara pasti melalui pemeriksaan penunjang radiologis dan laboratorium. Tatalaksana dapat berupa steroid namun perlu dilakukan studi untuk mengembangkan pengobatan lebih lanjut dalam memberikan tatalaksana yang tepat.

\section{Referensi}

Allen J. 2006. Acute eosinophilic pneumonia, Semin. Respir. Crit. Care Med. 27: 142-147.

Aokage T, Tsukahara K, Fukuda Y, Tokioka F, Taniguchi A, Naito H, Nakao A. 2019. Respiratory Medicine Case Report. 26(2019):87-90

Cheng T. 2014. Chemical evaluation of electronic cigarettes. Tobacco control. 23 Suppl 2: ii11ii17.

Christiani DC, 2019. Vaping-Induced Lung Injury. The new england and journal of medicine.

Cho JH, Shin E, Moon S-S. 2011. Electronic-Cigarette Smoking Experience Among Adolescents. Journal of Adolescent Health. 542-546

Davidson K, Brancato A, Heetderks P, Mansour W, Matheis E, Nario M, Rajagopalan S, et al. 2019. Outbreak of electronic-cigarette-associated acute lipoid pneumonia — North Carolina, July-August 2019. MMWR Morb Mortal Wkly Rep 2019; 68: 784-6

Elsa MS, Nadjib M. 2019. Determinan rokok elektrik di Indonesia : data SUSENAS (Survei Sosial Ekonomi Nasional) tahun 2017. BKM Journal of Community Medicine and Public Health. 35(2):41-48

Floyd EL, Queimado L, Wang J, Re- gens JL, Johnson DL. 2018. Electronic cigarette power affects count concentration and particle size distribution of vaping aero- sol. PLoS One. 13(12): e0210147.

Goniewicz ML, Lingas EO, Hajek P. 2013. Patterns of electronic cigarette use and user beliefs about their safety and benefits: an internet survey. Drug and alcohol review. 32(2): 133140

Henry TS, Kligerman SJ, Raptis CA, Mann H, Sechrist JW, Kanne JP. 2020. Imaging Findings of Vaping Associated Lung Injury. AJR. 214:1-8

Itoh M, Aoshiba K, Herai Y, Nakamura H, Takemura T. 2018. Lung injury associated with electronic cigarettes inhalation diagnosed by transbronchial lung biopsy. Respirology Case Reports, 6 (1), 2018, e00282.

Kamada T, Yamashita Y, Tomioka H. 2016. Acute eosinophilic pneumonia following heat-notburn cigarette smoking, Respirol. Case Rep. 4 (2016) e00190.

Kemenkes RI. 2018. Situasi Umum Konsumsi Tembakau di Indonesia. Jakarta : Pusat Data dan Informasi Kementrian Kesehatan RI.

Khan MS, Khateeb F, Akhtar J, Khan Z, Lal A, Kholodovych V, Hammersley J. 2018. Organizing pneumonia related to elec- tronic cigarette use: a case report and re- view of literature. Clin Respir J. 12: 1295-9.

Layden JE, Ghinai I, Pray I, Kimball A, Layer M, Tenforde M, Navon L, et al. 2019. Pulmonary Illness Related to E-Cigarette Use in Illinois and Wisconsin-Preliminary Report. The New England Journal of Medicine. 1-14

Maddock SD, Cirulis MM, Callahan SJ, Keenan LM, Pirozzi CS, Raman SM, Aberegg SK. 2019. Pulmonary lipid- laden macrophages and vaping. N Engl J Med. DOI: 10.1056/ NEJMc1912038. 
Mantilla, RD, Darnell RT, Sofi U. 2016. Vapor Lung: Bronchiolitis Obliterans Organizing Pneumonia (BOOP) in Patient with E-Cigarette Use, in D22. REDUCING HARMS OF TOBACCO USE. 2016, American Thoracic Society. p. A6513-A6513.

McCauley L, Markin C, Hosmer D. 2012. An unexpected consequence of electronic cigarette use. Chest. 141: 1110-3.

Ndunda PM, Muutu TM. 2019. Electronic Cigarette Use is Associated With a Higher Risk of Stroke. AHA Journal. 50(Suppl 1).

Sulaiman S, Anggraini A. 2017. Sosialisasi Pencegahan Kasus Stroke Pada Lanjut Usia Di Desa Hamparan Perak Kecamatan. Stikes Siti Hajar. Medan. Jurnal Amaliah 1(2): 70-74

Tobacco Control Support Centre-IAKMI. Kementrian Kesehatan. 2015. Bunga Rampai Fakta Tembakau dan Permasalahannya di Indonesia Tahun 2014. Jakarta: Tobacco Control Support Centre-IAKMI.

Triantafyllou GA, Tiberio PJ, Zou RH, Lamberty PE, Lynch MJ, Kreit JW, Gladwin MT, Morris A, Chiarchiaro J. 2019. Vaping-Associated Acute Lung Injury: A Case Series. American Thoracic Society. 1-9 